\title{
DR-62
}

\section{FUNCTIONAL PROPERTIES OF THE PROTEIN FEED ADDITIVES BASED ON THE WASTES AND BY-PRODUCTS OF SLAUGHTER AND PROCESSING OF POULTRY}

\author{
D. Y. Ismailova, ${ }^{1 *}$ V. G. Volik, ${ }^{1}$ T. V. Fedorova, ${ }^{2}$ V. S. Lukashenko, ${ }^{3}$ I. P. Saleeva ${ }^{3}$ \\ ${ }^{1}$ All-Russian Research Institute of Poultry Processing - branch of the Federal Scientific Center \\ "All-Russian Research and Technological Institute of Poultry" of Russian Academy of Sciences, \\ Rzhavki, Solnechnogorsk District, Moscow Province, 141552 Russia; \\ ${ }^{2}$ Federal Research Centre "Fundamentals of Biotechnology" \\ of Russian Academy of Sciences, Moscow, Leninsky Ave, 33, Bldg. 2, 119071 Russia; \\ ${ }^{3}$ Federal Scientific Center "All-Russian Research and Technological Institute of Poultry" of Russian \\ Academy of Sciences, Ptitsegradskaya St, 10, Sergiev Posad,, Moscow Province, 141311 Russia. \\ *E-mail: dilaramis08@mail.ru
}

\begin{abstract}
The distribution of molecular weights (MW) of the peptides and anti-oxidative capacity (as oxygen radical absorbing capacity, ORAC) were studied in new protein feed additives produced by the short-term thermal hydrolysis and subsequent fermentation by proteolytic enzymes of the wastes and by-products of slaughter and processing of poultry. Abstract. The highest amounts of this fraction was found in FM (83.58\%) and in new "Fermented Additive" (FA, ca. 80\%); PM and new "Hydrolyzed Additive" (HA) contained 65.16 and $53.58 \%$ of this fraction, respectively. The percentage of heavyweight peptides (> $10 \mathrm{KDa}$ ) in FM and FA was ca. 8\% and 5\%, respectively, while in PM and HA 17.55 and $32.77 \%$.

ORAC of hydrophilic fraction of all additives (to peroxide radical) was within the range of 152$2000 \mu \mathrm{M}$ of trolox equivalents (TE) per $1 \mathrm{~g}$. The highest ORAC was found in FA (ca. $1980 \mu \mathrm{M} \mathrm{TE} / \mathrm{g}$ ), the lowest in FM (ca. $153 \mu \mathrm{M}$ TE/g); ORAC in PM and HA was similar and fell within the range 400$520 \mu \mathrm{M} \mathrm{TE} / \mathrm{g}$.

The conclusion was made that new protein feed additives have certain unique properties including anti-radical and antioxidative activity. MW of the most peptides within FA is below 3 KDa. Introduction of these additives to diets for animals and poultry can improve the quality of the feeds; allow for the saving on the expensive fishmeal; solve the problem of the utilization of poultry slaughter wastes and improve the ecological condition of poultry processing enterprises.
\end{abstract}

